\title{
Pemulihan Motilitas Usus yang Terlambat Lebih Sering Terjadi pada Operasi Onkologi Ginekologi
}

\author{
Adrian Goenawan, Herman Susanto, Siti Salima \\ Departemen Obstetri dan Ginekologi Fakultas Kedokteran Universitas Padjadjaran \\ Rumah Sakit Dr. Hasan Sadikin Bandung \\ Korespondensi: Adrian Goenawan, Email: Adrian.goenawan@gmail.com
}

\begin{abstract}
Abstrak
Tujuan: Komplikasi selama operasi dan pasca operasi tetap menjadi beban bagi ahli bedah dan pasien serta keluarga mereka juga. Ileus adalah salah satunya, terutama di pembedahan pada rongga peritoneum. Keterlambatan dalam pemulihan motilitas usus dapat menyebabkan ileus. Prosedur sederhana untuk memeriksa pemulihan motilitas usus adalah dengan memeriksa onset bising usus, flatus dan BAB.

Metode: Secara retrospektif catatan wanita yang menjalani operasi ginekologi mayor (kelompok A) atau operasi onkologi (kelompok B) dan dievaluasi berdasarkan usia dan indikasi operasi. Hasil darah pra operasi, lama operasi, dan komplikasi selama operasi dicatat. Permulaan bising usus, flatus dan BAB dianalisis dan dibandingkan antara kedua kelompok.

Hasil: Sebanyak 889 pasient tidak ada perbedaan antara kelompok usia, kadar hemoglobin serum pra dan pascaoperasi, leukosit sebelum dan sesudah operasi, memerlukan transfusi darah $(p>0,05)$, namun terdapat perbedaan yang signifikan pada lama operasi.

Kesimpulan: Pemulihan motilitas usus lebih awal pada pasien yang menjalani operasi ginekologi dibandingkan dengan kelompok onkologi baik secara klinis maupun secara statistik.
\end{abstract}

Kata kunci: motilitas usus, ileus, pasca operasi, ginekologi, onkologi

\section{Delayed Recovery of Intestinal Motility Occurs more Common in Oncology Gynecology Operation}

\begin{abstract}
Objective: Complications during operation and postoperatively remain the burden for the surgeon and patients and their relatives as well. Ileus is one of those, especially those enters the peritoneal cavity. Delay in the recovery of intestinal motility can cause ileus. Simple procedures to check the recovery of intestinal motility are by checking the onset of bowel sound, flatulence and return of bowel movement.

Methods: We retrospectively identified records of women who underwent major gynecologic surgery (group A) or oncologic surgery (group B). All patients were evaluated by age, relevant medical history, previous surgery, and indication for operation. Preoperative blood results, duration of operation, and complication during the operation were noted. Onset of bowel sound, flatulence and return of bowel movement analyzed and compared between the two groups.

Results: Total of 889 patients were studied. There was no difference between groups in term of age, pre-and postoperative serum hemoglobin, pre- and postoperative leucocyte, needing blood transfusion and duration of operation ( $p>0.05)$.

Conclusion: There is earlier recovery of intestinal motility in patients undergone gynecologic surgery compared to those in the oncologic groups, clinically and statistically significant.
\end{abstract}

Keywords: intestinal motility, ileus, postoperative, gynecology, oncology 


\section{Pendahuluan}

Angka kejadian ileus pasca operasi perabdomen mencapai $10,3 \%$. Ileus pasca operasi didefinisikan sebagai tidak kembalinya fungsi usus setelah 3-5 hari pasca operasi yang ditandai dengan flatus dan defekasi. ${ }^{5}$ Pada penelitian Abd-El-Maeboud ditemukan rerata waktu antara selesainya seksio sesarea dan flatus pertama adalah 24,4 jam, sedangkan bising usus pertama terdengar setelah 30 jam. $^{6}$ Gejala utama ileus pasca operasi adalah muntah, mual, dan nyeri perut dan ditandai dengan 2 atau lebih dari tanda-tanda berikut: mual/muntah, ketidakmampuan untuk menerima makanan setelah 24 jam, tidak adanya flatus setelah 24 jam, distensi dan konfirmasi radiologis pada hari ke-4 atau lebih tanpa perbaikan sebelumnya. Beberapa faktor yang diketahui mempengaruhi kejadian ileus pasca operasi adalah: blok respon sinyal ekstra serebral (lokal dan sistemik), efek hormonal, dan gangguan endokrinologikal. ${ }^{4}$

Pemberian makan enteral dini pasca operasi via oral atau nasoenterik dianjurkan sebagai metode untuk menurunkan durasi ileus pasca operasi. Logika dibelakang pemberian makan dini adalah bahwa asupan makan dapat (1) menstimulasi refleks yang memproduksi aktivitas propulsi terkoordinasi, dan (2) memicu sekresi hormon gastrointestinal.

Tujuan penelitian ini adalah untuk mengidentifikasi perbandingan rerata waktu munculnya bunyi bising usus pasca-operasi ginekologi dibandingkan dengan onkologi, untuk mengidentifikasi perbandingan rerata waktu munculnya flatus pasca-operasi ginekologi dibandingkan dengan onkologi, untuk mengidentifikasi perbandingan rerata waktu terjadinya buang air besar pascaoperasi ginekologi dibandingkan dengan onkologi

\section{Metode}

Rancangan penelitian dalam penelitian ini adalah Retrospective Cross-sectional karena pengambilan data dari Bagian Rekam Medik RSUP Dr. Hasan Sadikin, Bandung dari Januari 2015 - Desember 2016. Penelitian ini merupakan hospital based study yang bersifat analitik karena dalam penelitian ini hanya dilakukan pengamatan dan mencari hubungan antar-variabel penelitian menurut keadaan alamiah tanpa melakukan manipulasi atau intervensi. Penelitian ini dilaksanakan di RSUP Dr. Hasan Sadikin pada bulan Januari 2015 sampai dengan Desember 2016. Penelitian ini menggunakan total sampel atau sampel jenuh yaitu seluruh anggota populasi menjadi sampel pada penelitian ini. Subyek penelitian ini adalah semua pasien yang pernah dirawat dan dilakukan tindakan operasi ginekologi atau onkologi di bagian Obstetri Ginekologi RSUP Dr. Hasan Sadikin, Bandung periode 1 Januari 2015-31 Desember 2016.

Kriteria inklusi pada penelitian ini adalah semua pasien dari seluruh kelompok usia dan pasien yang telah dilakukan tindakan operasi ginekologi atau onkologi sebagai terapi, dalam hal ini yang termasuk di dalamnya adalah surgical staging, radikal histerektomi, histerektomi total dan histerektomi supravaginal per abdominam, salpingoovarektomi unilateral dan bilateral, serta kistektomi. Sedangkan kriteria eksklusi pada penelitian ini adalah pasien yang setelah dilakukan operasi mendapatkan intervensi awal seperti mobilisasi dini dan early feeding serta apabila ditemukan variabel yang tidak lengkap

Penelitian ini dimulai dengan mengidentifikasi rekam medis pasien rawat inap, kemudian dilakukan penelusuran faktor demografi dan klinis berdasarkan diagnosis operasional. Data yang telah dikumpulkan selanjutnya akan diolah dan hasilnya disajikan secara analitik. Penghitungan analitik 
dilakukan menggunakan software IBM SPSS Statictics. Kedua grup dibandingkan dengan menggunakan two tailed t-test untuk variabel kontinu dan Chi-square atau Fisher's exact test untuk variabel kategori. Semua perbandingan akan digunakan $\mathrm{p}<0.05$ untuk dapat dikatakan signifikan.

\section{Hasil}

Sebanyak total 889 pasien yang menjalani operasi ginekologi dan onkologi di Departemen Obstetri dan Ginekologi RSUP Dr. Hasan Sadikin, Bandung sesuai dengan kriteria inklusi dab dimasukkan ke dalam penelitian ini. Pasien dikelompokkan menjadi dua, kelompok A yaitu pasien yang menjalani operasi ginekologi dan kelompok B yaitu pasien yang menjalani operasi onkologi. Tidak terdapat perbedaan antara kedua kelompok penelitian mengenai variabel umur, kadar serum hemoglobin predan pasca operasi, kadar serum leukosit pre- dan pasca operasi, kebutuhan akan transfusi darah $(\mathrm{p}>0.05)$, namun terdapat perbedaan yang signifikan pada lama operasi antara kedua grup tersebut.

Pada kelompok A, ditemukan bahwa waktu yang dibutuhkan untuk mendengar bising usus normal adalah $15.6 \pm 3.48$ jam, sementara waktu yang dibutuhkan pada kelompok B adalah $18.3 \pm 3.55$ jam. Hasil penelitian ini menunjukkan waktu yang lebih awal dari hasil penelitian Hardono yang menemukan bahwa rerata waktu yang dibutuhkan untuk kembalinya motilitas usus seperti keadaan semula sebelum pembedahan adalah sekitar 25.13 jam. Sementara itu, waktu yang dibutuhkan untuk mendengar bising usus normal pada penelitian serupa di Mesir pada responden yang menjalani seksio sesaria adalah sekitar $15.6 \pm 3.7$ jam. Penelitian lain pada semua pasien operasi ginekologi dengan berbagai indikasi mendokumentasikan bahwa waktu untuk bising usus pertama adalah 6.08 \pm 1.8 jam. ${ }^{5,15,16}$

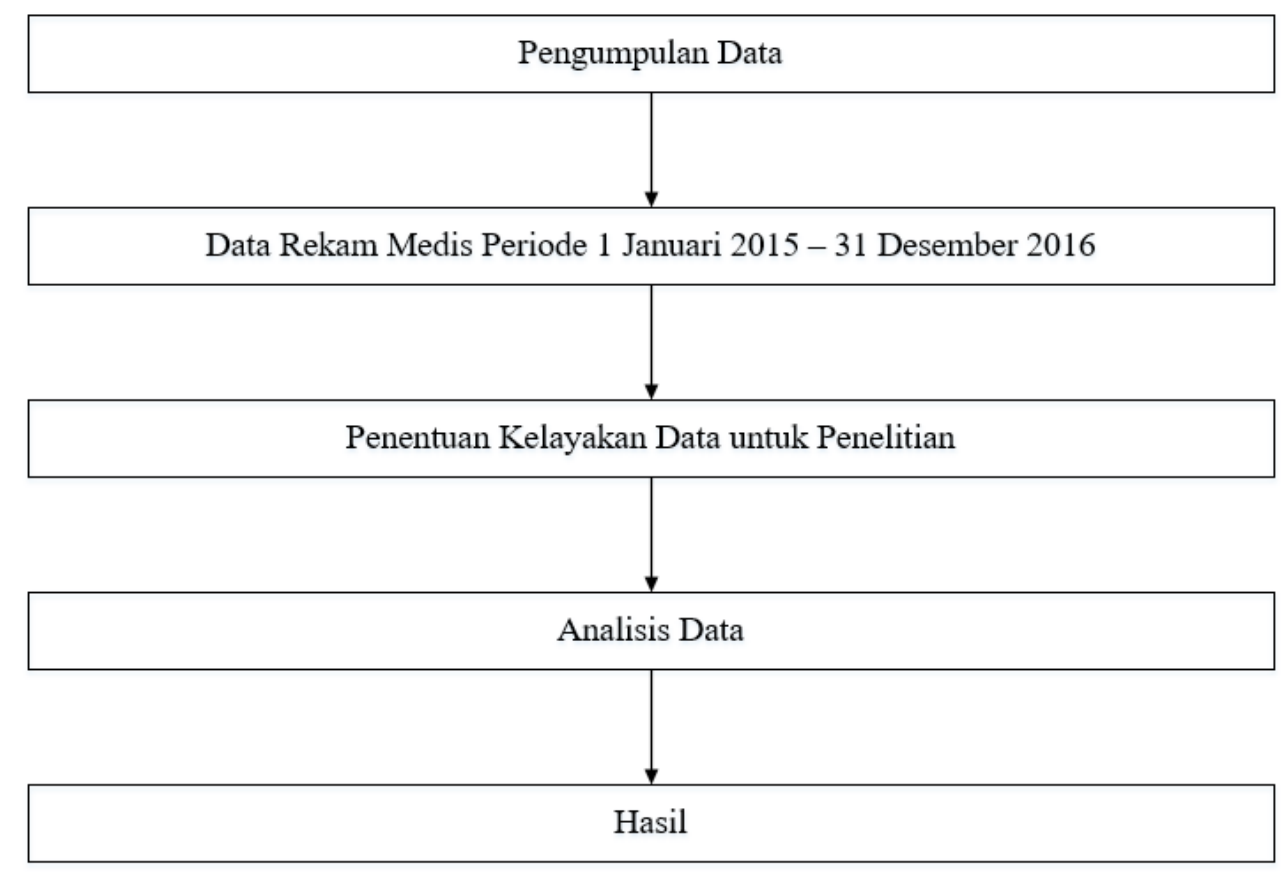

Gambar 1. Alur Penelitian 
Tabel 1 Karakteristik Demografi

\begin{tabular}{lccc}
\hline & $\begin{array}{c}\text { Grup A } \\
(\mathbf{n}=\mathbf{4 8 3})\end{array}$ & $\begin{array}{c}\text { Grup B } \\
(\mathbf{n}=\mathbf{4 0 6})\end{array}$ & Nilai p* \\
\hline $\begin{array}{l}\text { Umur } \\
\begin{array}{l}\text { Riwayat operasi } \\
\text { sebelumnya }\end{array}\end{array}$ & $35.61(22.8)$ & $43.53(25.7)$ & 0.202 \\
\hline
\end{tabular}

*Uji Chi-square

Tabel 2 Karakteristik Intra- dan Pasca operasi

\begin{tabular}{lccc}
\hline & $\begin{array}{c}\text { Grup A } \\
(\mathrm{n}=483)\end{array}$ & $\begin{array}{c}\text { Grup B } \\
(\mathrm{n}=406)\end{array}$ & Nilai p* \\
\hline Adhesi & $65(13.46)$ & $74(18.27)$ & 0.063 \\
Transfusi darah & $33(6.83)$ & $45(11.08)$ & 0.099 \\
Lama operasi (menit) & $167.3(49.5)$ & $242.7(72.9)$ & $<0.0001$ \\
$\begin{array}{l}\text { Demam } \\
\begin{array}{l}\text { Distensi abdomen } \\
\text { (pascaoperasi) }\end{array}\end{array}$ & 0 & 0 & - \\
$\begin{array}{l}\text { Muntah (pascaoperasi) } \\
\text { Ileus (pascaoperasi) }\end{array}$ & $5(1.03)$ & $7(1.72)$ & 0.552 \\
\hline
\end{tabular}

*Uji Chi-square

Tabel 3 Hasil Lab pre- dan Pascaoperasi

\begin{tabular}{lcccc}
\hline & $\begin{array}{c}\text { Grup A } \\
(\mathrm{n}=483)\end{array}$ & $\begin{array}{c}\text { Grup B } \\
(\mathrm{n}=406)\end{array}$ & $\begin{array}{c}\text { Perbedaan antara } \\
\text { mean }(\text { CI 95\%) }\end{array}$ & Nilai p* \\
\hline $\begin{array}{l}\text { Hemoglobin } \\
\text { (pre-operasi) }\end{array}$ & $11.63(2.95)$ & $11.34(1.72)$ & $-0.04-0.62$ & 0.081 \\
$\begin{array}{l}\text { Hemoglobin } \\
\text { (pascaoperasi) }\end{array}$ & $8.38(1.22)$ & $8.42(1.74)$ & $-0.26-0.16$ & 0.688 \\
$\begin{array}{l}\text { Leukosit } \\
\text { pre-operasi) }\end{array}$ & $8745(3376)$ & $8968(2957)$ & $-645.2-199.2$ & 0.300 \\
$\begin{array}{l}\text { Leukosit } \\
\text { (pascaoperasi) }\end{array}$ & $11385(3886)$ & $10954(3451)$ & $-57.63-919.63$ & 0.083 \\
\hline
\end{tabular}

*Uji Chi-square

Tabel 4 Hasil Penelitian Primer

*Uji Chi-square

\begin{tabular}{lcccc}
\hline & $\begin{array}{c}\text { Grup A } \\
(\mathrm{n}=483)\end{array}$ & $\begin{array}{c}\text { Grup B } \\
(\mathrm{n}=406)\end{array}$ & $\begin{array}{c}\text { Perbedaan } \\
\text { antara mean } \\
(\mathrm{CI} 95 \%)\end{array}$ & p value \\
\hline $\begin{array}{l}\text { Terdengarnya suara } \\
\text { bising usus }\end{array}$ & $15.6 \pm 3.48$ & $18.3 \pm 3.55$ & $2.24-3.17$ & $<0.0001$ \\
Keluar flatus & $24.4 \pm 7.12$ & $30.0 \pm 5.43$ & $4.75-6.45$ & $<0.0001$ \\
Keluar BAB & $30.4 \pm 8.20$ & $32.8 \pm 6.32$ & $1.42-3.38$ & $<0.0001$ \\
Lama rawat & $70.6 \pm 8.19$ & $77.8 \pm 12.85$ & $5.80-8.60$ & $<0.0001$ \\
\hline
\end{tabular}


Rerata waktu untuk pasase flatus pertama pada kelompok A dalam penelitian ini adalah $24.4 \pm 7.12$ jam, sementara waktu yang dibutuhkan pada kelompok B adalah $30 \pm 5.43$ jam. Penelitian oleh Abd-ElMaeboud mencatat bahwa rerata waktu untuk pasase flatus pertama pada responden yang menjalani seksio sesaria adalah $24.4 \pm$ 7.1 jam. Hasil yang juga serupa ditemukan penelitian lain pada semua pasien operasi ginekologi dengan berbagai indikasi, yaitu $23.5 \pm 10.7$ jam. Meskipun demikian, hasil pada penelitian ini menujukkan waktu yang jauh lebih awal dibandingkan hasil penelitian di Swedia, yang menemukan bahwa waktu yang dibutuhkan untuk pasase flatus pertama adalah $5.6 \pm 4.4$ hari. $^{4,5,15}$

\section{Pembahasan}

Secara keseluruhan, waktu yang dibutuhkan untuk mendengar bising usus normal, waktu untuk pasase flatus pertama, dan waktu hingga defekasi pertama pada kelompokA ditemukan lebih awal dari kelompok B. Penggunaan anestesi intravena tambahan pasca operasi juga kemungkinan memengaruhi waktu yang dibutuhkan untuk pemulihan motilitas usus. Selanjutnya, tipe operasi, misalnya laparotomi atau laparoskopi juga turut mempengaruhi waktu pemulihan motilitas usus. Operasi onkologi terutama pada stadium lanjut biasanya membutuhkan tipe operasi eksploratif, sehingga memperbesar luka operasi dan memperlambat waktu penyembuhan pasca operasi. Stadium tumor lanjut atau tumor dengan metastasis jauh kemungkinan juga secara keseluruhan mempengaruhi metabolisme tubuh sehingga menyebabkan pemulihan fungsi usus pada pasien yang menjalani operasi onkologi juga lebih lambat. Selain itu, pasien onkologi juga umumnya lebih rentan terhadap penurunan fungsi tubuh dan berat badan yang tidak diharapkan, sehingga juga lebih rentan mengalami komplikasi lain pasca operasi yang mungkin mempengaruhi pemulihan motilitas usus. ${ }^{3,4,15,17,18}$

Temuan pada penelitian ini mengindikasikan adanya pemulihan motilitas usus yang lebih awal pada pasien yang menjalani operasi ginekologi dibandingkan dengan operasi onkologi; terdapat perbedaan yang signifikan secara klinis maupun statistik antara keduanya $(\mathrm{p}<0.05)$. Selain itu, tidak ditemukan adanyaileus pada kedua kelompok. Simpulan terdapat pengembalian motilitas usus yang lebih cepat pada pasien yang dilakukan operasi ginekologi dibandingkan kelompok pasien onkologi, dengan perbedaan yang ditemukan menunjukkan hasil secara klinis dan statistik yang signifikan.

\section{Daftar Pustaka}

1. Doll KM, Snavely AC, Kalinowski A, Irwin DE, Bensen JT, Bae-Jump V, dkk. Preoperative quality of life and surgical outcomes in gynecologic oncology patients: a new predictor of operative risk? Gynecol Oncol. 2014;133(3):54651.

2. Lachiewicz MP, Moulton LJ, Jaiyeoba O. Pelvic surgical site infections in gynecologic surgery. Infect Dis Obstet Gynecol. 2015;2015:1-8.

3. Erekson EA, Yip SO, Ciarleglio MM, Fried TR. Postoperative complications after gynecologic surgery. Obstet Gynecol. 2011;118(4):785-93.

4. Anersson $\mathrm{T}$, Bjersa $\mathrm{K}$, Falk $\mathrm{K}$, Olsen MF. Effects of Chewing Gum Against Postoperative Ileus After Pancreaticoduodenectomy-A Randomized Controlled Trial. BMC Research Notes. 2015;8(37):1-5.

5. Senol T, Polat M, Ozkaya E, Unver G, Karateke A. Effect of Gum chewing on intestinal functions after gynecological operations: A Randomized Controlled Study. Gynecol Obstet Reprod Med. 2016;22(3):160-4. 
6. Iyer R, Gentry-Maharaj A, Nordin A, Bumell M, Liston R, Manchanda R, dkk. Predictors of complications in gynaecological oncological surgery: A Prospective Multicentre Study (UKGOSOC-UK Gynaecological Oncology Surgical Outcomes and Complications). $\mathrm{Br} \mathrm{J}$ Cancer. 2015;112:475-84.

7. Wysham WZ, Kim KH, Roberts JM, Sullivan SA, Campbell SB, Roque DR, dkk. Obesity and perioperative pulmonary complications in robotic gynecologic surgery. Am J Obstet Gynecol. 2015;213(33):e1-e7.

8. Jernigan AM, Chen CC, Sewell C. A randomized trial of chewing gum to prevent postoperative ileus after laparotomy for benign gynecologic surgery. Int $\mathrm{j}$ Gynaecol Obstet. 2014;127(3):279-82.

9. Park JY, Kim TJ, Kang HJ, Lee YY, Choi $\mathrm{CH}$, Lee JW, dkk. Laparoendoscopic single site (less) surgery in benign gynecology: perioperative and late complications of 515 Cases. Eur J Obstet Gynecol Reprod Biol. 2013;167(2):2158.

10. Behm B, Stollman N. Postoperative Ileus: Etiologies and interventions. Clin Gastroenterol . 2003;1:71-80.

11. Thompson M, Magnuson B. Management of postoperative ileus. Pharmacology Update. 2012;35(3):213-7.
12. 1Uemura $\mathrm{K}$, Tatewaki M, Harris MB, Ueno T, Mantyh CR, Pappas TN, dkk. Magnitude of Abdominal Incision Affects the Duration of postoperative ileus in rats. Surg Endosc. 2004;18:606-10.

13. KehletH,HolteK. Review of postoperative ileus. Am J Surg. 2001;182:3S-10S.

14. Luckey A, Livingston E, Tache Y. Mechanisms and Treatment of postoperative ileus. Arch Surg. 2003;138:206-14.

15. Abd-El-Maeboud KH, Ibrahim MI, Firky MF. Gum chewing stimulates early return of bowel motility after caesarean section. BJOG. 2009;116(10):1334-9.

16. 16. Hardono HR, Somantri I. Pengaruh mengunyah permen karet terhadap durasi waktu pasca operasi ileus pasca bedah abdomen. Ilmu Keperawatan Respati. 2015;2(1).

17. 17. Gala RB, Margulies R, Steinberg A, Murphy M, Lukban J, Jeppson P, dkk. Systematic review of robotic surgery in gynecology: Robotic Techniques Compared With Laparoscopy and Laparotomy. J Minim Invasive Gynecol. 2014;21(3):353-61.

18. Vasilios P, Evangelos C, Paraskevi K, Diamanto K, Despina P, DimitriosEfthymios V. Patient Controlled Epidural vs intravenous analgesia in gynecologic oncology: A Systematic Review. HJOG. 2016;15(2):34-40. 